\title{
STUDI ALIRAN AIR PADA BALL VALVE DAN BUTTERFLY VALVE MENGGUNAKAN METODE SIMULASI COMPUTATIONAL FLUID DYNAMICS
}

\author{
Rizky Arman ${ }^{1}$, Yovial Mahyoedin ${ }^{1}$, Kaidir $^{1}$, Nando Desilpa $^{1}$ \\ ${ }^{1}$ Program Studi Teknik Mesin Fakultas Teknologi Industri Universitas Bung hatta \\ Jalan Gajah Mada No. 19 Olo Nanggalo, Padang 25143 \\ Email: rizky.arm@gmail.com
}

\begin{abstract}
ABSTRAK
Valve adalah alat mekanis yang mengatur aliran atau tekanan cairan. Fungsinya adalah menutup atau membuka aliran, mengontrol laju aliran, mengalihkan aliran, mencegah aliran balik, mengontrol tekanan, atau mengurangi tekanan. Masalah yang umumnya ditemui adalah penutupan valve tidak sempurna dikarenakan adanya kotoran-kotoran yang menghalangi penutupnya untuk menutup secara sempurna. Penanganannya yang paling sederhana yaitu membersihkan dudukan dari kotoran-kotoran tadi secara intensif dan dilakukan pelumasan. Penelitian ini bertujuan untuk menjelaskan gambaran tentang simulasi aliran pada ball valve dan butterfly valve. Dan menjelaskan perbandingan tekanan, temperatur dan kecepatan distribusi air pada dua jenis valve. Tekanan fluida pada kondisi tertutup berbeda dengan kondisi terbuka. Hal ini akan berdampak terhadap kekuatan ball valve dan butterfly valve. Tekanan yang besar atau melebihi spesifikasi akan mempengaruhi mekanisme kerja dan kekuatan material. Pengaruh tekanan ini menjadi sangat penting dalam ball valve dan butterfly valve karena tekanan fluida dengan temperatur, pada kondisi tertentu bisa di luar batas spesifikasi khususnya pada ball valve Sanitary SS316 Mounting Pad 3 inci dan butterfly valve Sanitary SS 3043 inci. Metode yang digunakan adalah Computational Fluid Dynamics dengan bantuan Software Flow Simulasi Solidwork 2014.
\end{abstract}

Kata Kunci: Ball and Butterfly Valve, Solidwork, Flow Simulasi, CFD, Tekanan, Temperatur, Kecepatan aliran.

\section{ABSTRACT}

Valves are mechanical devices that regulate fluid flow or pressure. Its function can close or open the flow, control the flow rate, divert flow, prevent backflow, control pressure, or reduce pressure. The problem commonly encountered is that the valve closure is not perfect due to the impurities that prevent the cover from closing completely. The simplest handling is to clean the holder from the dirts earlier and do lubrication. This study aims to explain the description of the flow simulation on ball valve and butterfly valve. This study also explain the comparison of pressure, temperature and velocity of water distribution in two types of valve heads. Fluid pressure under closed conditions is different from opening conditions. This will affect the strength of the ball valve and butterfly valve as a valve. Pressure that is large or exceeds specifications will affect the working mechanism and material strength. The effect of this pressure becomes very important in the ball valve and butterfly valve because of fluid pressure with temperature under certain conditions it can be out of the specification limits, especially in Sanitary SS316 Mounting Pad 3-inch ball valve and SS 3043 inch Sanitary butterfly valve. This method was used in research is Computational Fluid Dynamics by utilizing of Flow Simulation Solidwork 2014 Software.

Keywords: Ball Valve, Butterfly Valve, Solidwork 2014, Flow Simulation, CFD, Pressure, Temperature, Velocity.

\section{PENDAHULUAN}

Katup merupakan peralatan mekanik statis yang bertujuan untuk mengontrol aliran dan tekanan dalam suatu sistem perpipaan. Penggunaan katup dalam sistem perpipaan untuk mengatur aliran berupa cairan, gas, uap dan larutan lainnya. Jenis penggunaan katup sesuai dengan kebutuhan dan fungsi yang diinginkan. Dasar pemilihan katup adalah kekuatan kontrol aliran dan keselamatan (Boye dkk., 2016). Kita ketahui bahwa sangat dibutuhkan pekerja-pekerja yang ahli didalam bidangnya masing-masing, didalam industriindustri baik sekala kecil, menengah, maupun sekali besar sangat banyak kita jumpai katup yang berfungsi untuk membuka dan menutup saluran berupa minyak, air, udara serta gas. 
Setiap peralatan-peralatan yang digunakan dalam industri-industri tidaklah selalu dalam keadaan baik. Namun pada sewaktu-waktu akan mengalami kerusakan atau tidak berfungsi secara maksimal (Paul dkk.,).

Pemilihan jenis katup, bentuk desain dan jenis material memiliki peran yang sangat penting dalam kinerja dan kehandalan sistem. Valve banyak digunakan di berbagai industri terutama dalam sistem perpipaan. Fungsinya adalah untuk mengendalikan laju alir. Bagi produsen katup, sangat penting untuk mengetahui karakteristik temperatur dan tekanan di dalam valve. Valve mampu mengendalikan aliran cairan maupun gas dengan baik pada saat kondisi katup tertutup (full closed) atau terbuka (full open). Pengaruh penurunan bukaan valve mengakibatkan panjang resirkulasi meningkat. Peningkatan resirkulasi akan berpengaruh terhadap penurunan tekanan fluida. Penelitian zhang hanya melakukan analisis optimisasi desain terhadap ball valve dengan menggunakan flow simulation dan menyatakan bahwa hasil simulasi aliran dapat membantu dan bisa dijadikan indikator metode yang lebih baik (Utami, dkk.,).

\section{TINJAUAN PUSTAKA}

Valve adalah alat mekanis yang mengatur aliran atau tekanan cairan. Fungsinya bisa menutup atau membuka aliran, mengontrol laju aliran, mengalihkan aliran, mencegah aliran balik, mengontrol tekanan, atau mengurangi tekanan. Valve dapat diklasifikasikan berdasarkan metode berikut antara lain; jenis operasi, alam dan kondisi fisik aliran, kebocoran dan kontrol jenis aliran, metode operasi, fungsionalitas, dan lain-lain (Mandanaka dkk., 2016).

\subsection{Ball Valve}

Ball valve adalah katup dengan piringan berbentuk bola. Bagian katup yang mengontrol aliran melaluinya sphere yang memiliki lubang, atau port. Ketika katup ditutup, lubang tegak lurus terhadap ujung katup, dan aliran diblokir. Tuas akan sejalan dengan posisi port yang memungkinkan melihat posisi katup. Ball valve merupakan satu klasifikasi dengan butterfly valve dan plug valve dengan mekanisme seperempat putaran katup (Boye dkk., 2016).

Secara sederhana, ball valve sama saja dengan plug valve, tetapi bentuk disc nya berbeda. Dinamakan ball valve karena bentuk disc nya ini bulat seperti bola, dan bentuk body nya silinder. Ball valve merupakan katup dengan pengontrol aliran berbentuk disc seperti bola dan stem sebagai pemutar. Ball valve merupakan salah satu katup tipe gerak memutar. Ball valve digunakan juga sebagai on/off valve, fully opened atau fully closed valve, dan handal untuk aliran fluida yang mengandung partikel-partkel solid (slurry). Sama seperti plug valve, ball valve juga membuka dan menutup dengan cara rotasi pada disc sehingga dapat membuka dan menutup lebih cepat.

\subsection{Butterfly Valve}

Butterfly valve adalah salah satu jenis valveyang serba guna, dapat diaplikasikan pada sistem pemipaan dimanapun, di industri, pembangunan kapal, platform, di perumahan dan lain-lain. Selain itu butterfly valve bisa di pasang pada instalasi berbagai media yang melaluinya misalnya oleh cairan, gas, lumpur dengan berbagai tingkat tekanan dan suhu. Dengan sudut putaran kerja hanya $90^{\circ}$ memungkinkan valve jenis ini dapat dioperasikan dengan cepat namun tidak mampu di setting untuk ukuran aliran tertentu. Valve ini biasa disebut sebagai 
quarter turn valve. Dengan bahan penutup saluran sebuah disc valve ini digerakkan dengan poros aktuator yang terhubung dengan handel di sisi luar valve (Dantulwari, dkk, 2017).

Pada keadaan terbuka atau disk penutup pada posisi $0^{\circ}$ timbul aliran aerodinamis yang diakibatkan oleh disk tersebut. Meskipun kehilangan head sedikit lebih tinggi dari jenis valve ball valve. Namun kerugian itu lebih rendah dibandingkan dengan jenis globe valve. Berbagai jenis Butterfly valve dapat digunakan untuk berbagai media aliran, cairan dan gas maupun material yang agak padat seperti lumpur, bulb dll. Tekanan dan suhu material yang melalui valve ini jelas mempengaruhi material bahan pembuatannya, sehingga menjadi pertimbangan penting dalam perancangan.

\subsection{Computational Fluid Dynamics (CFD)}

Computational Fluid Dynamics (CFD) merupakan perangkat lunak yang memungkinkan analisis aliran fluida, termasuk perpindahan panas termal dan efek konduksi panas dalam cairan dan melalui batas-batas padat dari domain aliran. Penerapan CFD cukup meningkatkan kinerja mesin selama 20 tahun terakhir, sekaligus mengurangi waktu siklus desain. CFD berkaitan dengan solusi numerik persamaan diferensial yang mengatur aliran massa, momentum, dan energi dalam bergerak cairan. Kesulitan utama dalam informasi empiris yaitu terbatasnya rentang skala kecepatan fluida, suhu, waktu, atau panjang yang dihasilkan.

\section{METODOLOGI PENELITIAN}

Alur penelitian ini dapat dilihat pada diagram alir seperti pada Gambar 1 berikut. Alat yang digunakan dalam penelitian perencaan perbandingan model valve ini memakai software SolidWork dimana telah dilengkapi fitur 3D Experience Solution dan SolidWork Inspection.

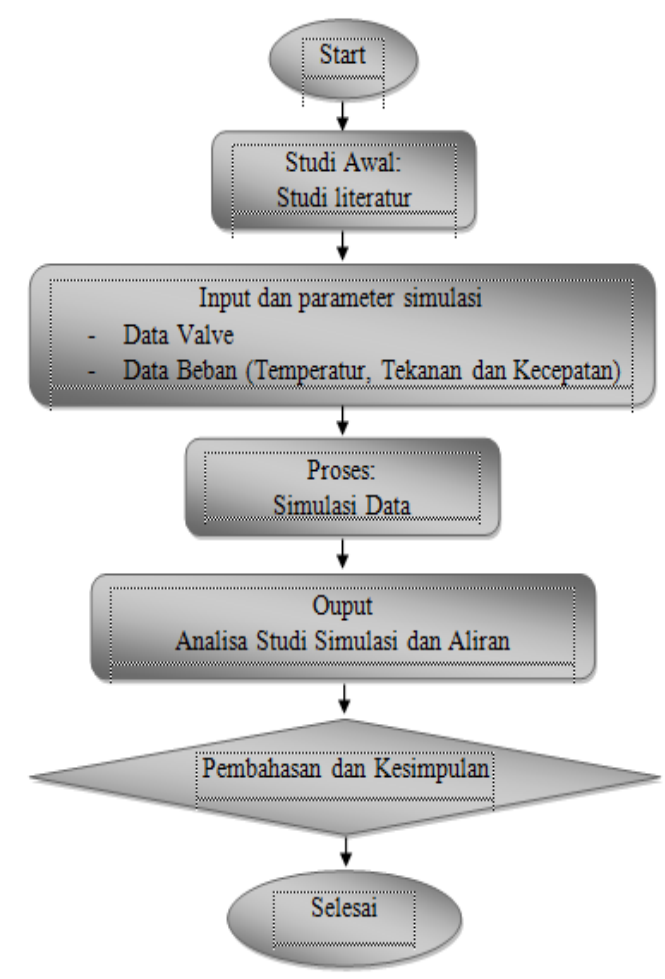

Gambar 1. Diagram Alir Penelitian 


\section{HASIL DAN PEMBAHASAN}

\subsection{Hasil Pemodelan 3D Ball Valve}

Hasil pemodelan ball valve dengan software SolidWork dapat dilihat pada gambar 2, sementara untuk butterfly valve dapat dilihat pada Gambar 3. Spesifikasi dan part dari ball dan butterfly valve dapat dilihat pada Tabel 1 dan 2.

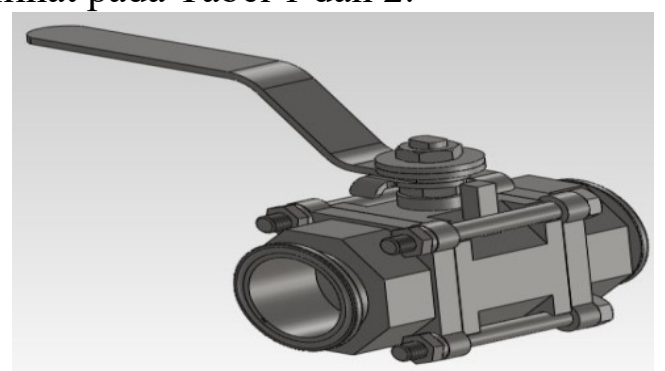

Gambar 2. Model 3D Ball Valve

Spesifikasi Ball Valve Sanitary SS316 Mounting Pad:

- Brand : Sankyo

- Material : carbon steel SS316

- Size : 3 inch

- Type : Ball Valve Sanitary SS 316 Mounting Pad

- Class : 1000 Psi

Tabel 1. Spesifikasi Ball Valve

\begin{tabular}{|c|c|c|}
\hline \multicolumn{3}{|c|}{ Media: Water, Oil } \\
\hline \multicolumn{3}{|c|}{ Nominal Pressure $(\mathrm{PN}): 63 \mathrm{kgf} / \mathrm{cm}^{2}$} \\
\hline \multicolumn{3}{|c|}{ Temperature: Normal $27^{0} \mathrm{C}$} \\
\hline No & Parts & Materials \\
\hline 1 & Body SUS 316 & SUS 316 \\
\hline 2 & Cap SUS 316 & SUS 316 \\
\hline 3 & Ball SUS 316 & SUS 316 \\
\hline 4 & Seat PTFE & PTFE \\
\hline 5 & Stem SUS 316 & SUS 316 \\
\hline 6 & Thrust Washer PTFE & PTFE \\
\hline 7 & Stem Packing PTFE & PTFE \\
\hline 8 & Bolt SUS 304 & SUS 304 \\
\hline 9 & Hex Nut SUS 304 & SUS 304 \\
\hline 10 & Spring Washer SUS 304 & SUS 304 \\
\hline 11 & Gland Nut SUS 304 & SUS 304 \\
\hline 12 & Spring Washer SUS 304 & SUS 304 \\
\hline 13 & Stem Nut SUS 304 & SUS 304 \\
\hline 14 & Handle SUS 304 & SUS 304 \\
\hline 15 & Plastic Cover Plastic & Plastic \\
\hline
\end{tabular}




\subsection{Hasil Pemodelan 3D Butterfly Valve}

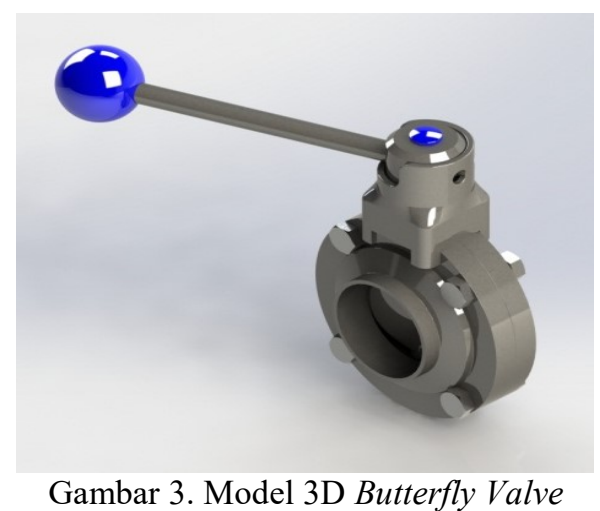

Spesifikasi Butterfly Valve Sanitary SS 304:

- Brand : Glacier Tanks

- Material : Stainless Steel 304 SS

- Size : 3 inch

- Type : Tri Clamp / Tri Clover

- Class : 1000 Psi

Tabel 2. Spesifikasi Butterfly Valve

\begin{tabular}{|c|l|l|l|}
\hline \multicolumn{3}{|c|}{ Media: Water, Oil } \\
\hline \multicolumn{3}{|c|}{ Nominal Pressure (PN): 63 kgf/cm ${ }^{2}$} \\
\hline \multicolumn{2}{|c|}{ Temperature: Normal 27 ${ }^{0} \mathrm{C}$} \\
\hline 1 & Nody & $\begin{array}{l}\text { Inox AISI 316L } \\
\text { / SS 316L }\end{array}$ & $\begin{array}{l}\text { Surface } \\
\text { Treatment } \\
\text { Polish }\end{array}$ \\
\hline 2 & Seat & EPDM & $\begin{array}{l}\text { Mechanical } \\
\text { Polish }\end{array}$ \\
\hline 3 & Disc & $\begin{array}{l}\text { Inox AISI 316L } \\
/ \text { SS 316L }\end{array}$ & $\begin{array}{l}\text { Mechanical } \\
\text { Polish }\end{array}$ \\
\hline 4 & Handle & $\begin{array}{l}\text { Inox AISI 316 / } \\
\text { SS 316 }\end{array}$ & $\begin{array}{l}\text { Mechanical } \\
\text { Polish }\end{array}$ \\
\hline 5 & Cap & $\begin{array}{l}\text { Plastic } \\
\text { Mechanical } \\
\text { Polish }\end{array}$ \\
\hline 6 & Bolt & $\begin{array}{l}\text { Inox AISI 304 / } \\
\text { SS 304 }\end{array}$ & $\begin{array}{l}\text { Mechanical } \\
\text { Polish }\end{array}$ \\
\hline 7 & Nut & $\begin{array}{l}\text { Inox AISI 304 / } \\
\text { SS 304 }\end{array}$ & $\begin{array}{l}\text { Mechanical } \\
\text { Polish }\end{array}$ \\
\hline
\end{tabular}

\subsection{Analisa Pembahasan Ball Valve Kondisi Full Open}

Perubahan tekanan, temperatur dan velocity berdasarkan hasil analisa metode flow simulation computational fluid dynamics terhadap ball valve dapat dilihat pada Gambar 4 . 


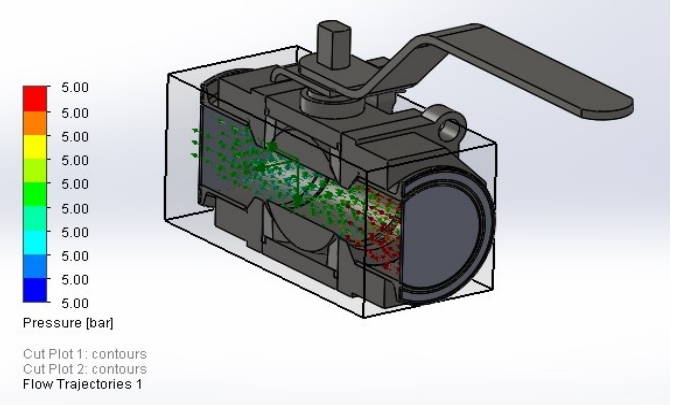

Gambar 4. Tekanan Fluida Ball Valve

Pada Gambar 4 diatas menunjukkan akibat tekanan fluida terjadi gesekan pembeban yang besar pada inlet dan pengurangan gesekan pembebanan pada outlet. Maka tekanan pada ball valve titik pembeban terbesarnya yaitu pada inlet. Grafik perubahan tekanan fluida dapat dilihat pada Gambar 5.

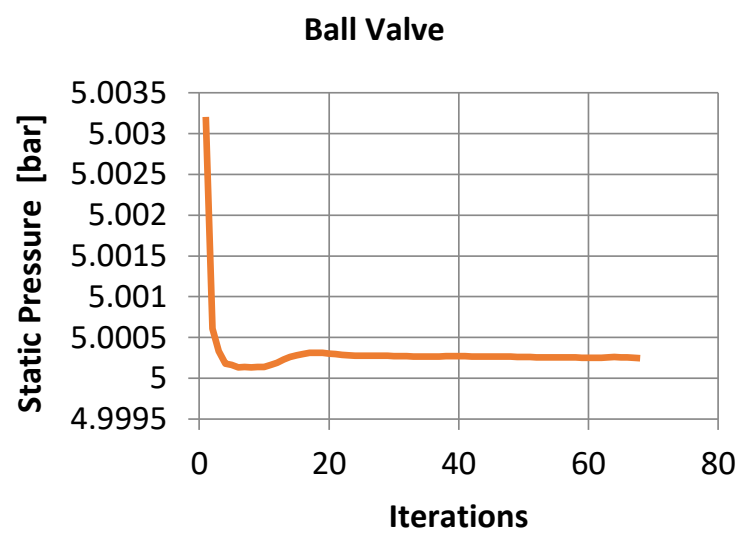

Gambar 5. Grafik Tekanan Fluida Ball Valve

Pada Gmbar 5, grafik diatas menunjukan pada saat kondisi full open, tekanan fluida juga tidak menunjukkan adanya peningkatan perubahan. Nilai perubahan tekanan fluida menunjukkan penurunan diantara 5,10 bar sampai dengan nilai minimum 5,03 bar.

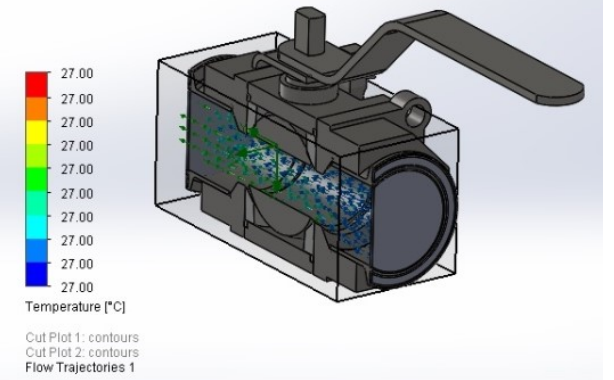

Gambar 6. Temperatur Fluida Ball Valve

Pada gambar 6 menunjukkan temperatur fluida alirannya konstan dan tidak terdapat pembeban yang besar pada inlet maupun outletnya. Grafik temperatur fluida dapat dilihat pada Gambar 7. 


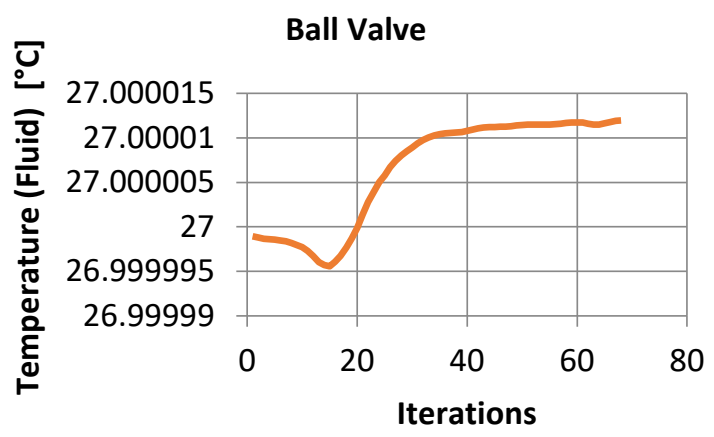

Gambar 7. Grafik Temperatur Fluida Ball Valve

Pada grafik diatas menunjukan pada saat kondisi full open, temperatur fluida menunjukkan adanya peningkatan perubahan. Nilai perubahan temperatur fluida menunjukkan peningkatan dan penurunan dari nilai awal $26,99^{\circ} \mathrm{C}$ turun ke $26,95^{\circ} \mathrm{C}$ lalu naik kembali sampai dengan nilai tertinggi $27,12^{\circ} \mathrm{C}$.
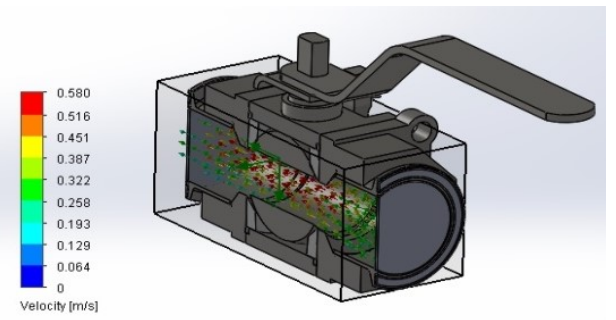

Gambar 8. Kecepatan Fluida Ball Valve

Pada Gambar 8 diatas menunjukkan kecepatan alira fluida terjadi perubahan di tengah dan terdapat pembeban yang besar pada saat bukaan katup. Grafik perubahan kecepatan fluida dapat dilihat pada Gambar 9.

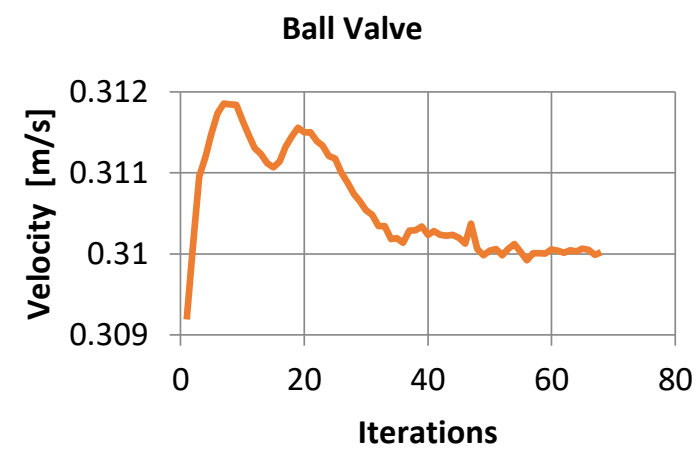

Gambar 9.Grafik Kecepatan Fluida Ball Valve

Pada Gambar 9 dan Tabel 3 menunjukan pada saat kondisi full open, kecepatan fluida terjadi perubahan peningkatan lalu mengalami penurunan. Nilai perubahan kecepatan fluida menunjukkan peningkatan $0,313 \mathrm{~m} / \mathrm{s}$ dan penurunan sampai $0,31 \mathrm{~m} / \mathrm{s}$.

Tabel 3. Analisa Metode Flow Simulation Computational Fluid Dynamics Pada Ball Valve

\begin{tabular}{|l|c|c|c|c|c|}
\hline Ball Valve & Unit & Value & $\begin{array}{c}\text { Averaged } \\
\text { Value }\end{array}$ & $\begin{array}{c}\text { Minimum } \\
\text { Value }\end{array}$ & $\begin{array}{c}\text { Maximum } \\
\text { Value }\end{array}$ \\
\hline Pressure & {$[\mathrm{bar}]$} & 4,95 & 5 & 4,95 & 5,35 \\
\hline
\end{tabular}




\begin{tabular}{|l|c|c|c|c|c|} 
Temperature & {$\left[{ }^{\circ} \mathrm{C}\right]$} & 26,99 & 27 & 26,99 & 27,12 \\
\hline Velocity & {$[\mathrm{m} / \mathrm{s}]$} & 0,31 & 0,5 & 0,31 & 0,313 \\
\hline
\end{tabular}

\subsection{Analisa Pembahasan Butterfly Valve Kondisi Full Open}

Perubahan tekanan, temperatur dan velocity berdasarkan hasil analisa metode flow simulation computational fluid dynamics terhadap butterfly valve dapat dilihat pada Gambar 10.

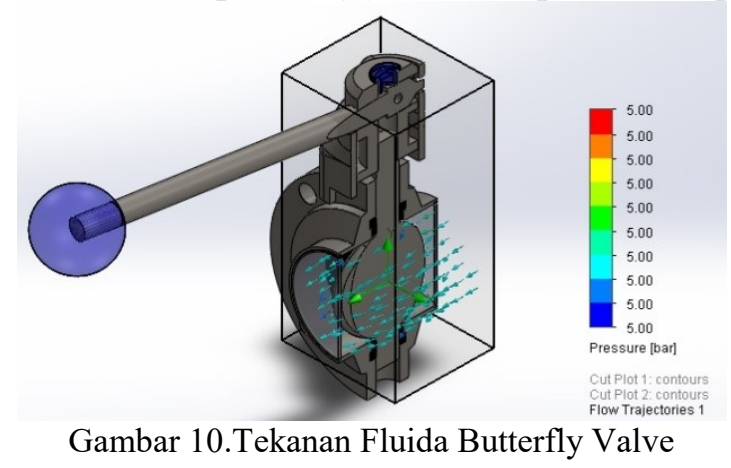

Pada gambar diatas menunjukkan pada tekanan fluidanya konstan. Maka tidak ada titik pembebanan terbesar pada tekanan butterfly valve. Grafik perubahan tekanan fluida dapat dilihat pada Gambar 11.

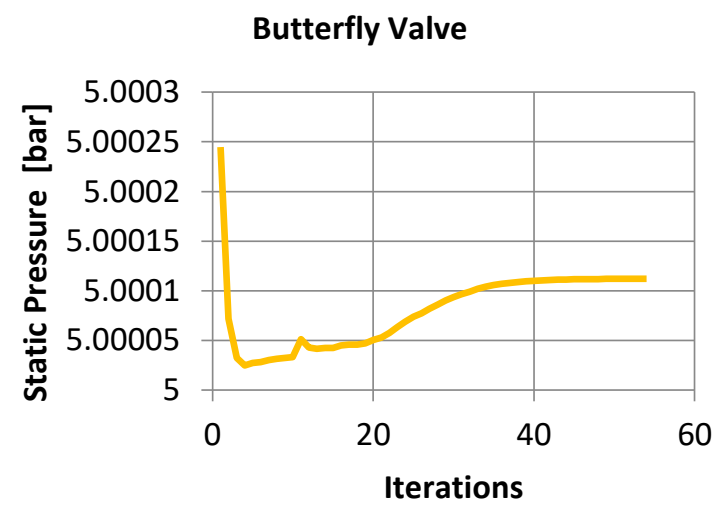

Gambar 11.Grafik Tekanan Fluida Butterfly Valve

Pada Gambar 11, menunjukan saat kondisi full open, tekanan fluida menunjukkan adanya peningkatan perubahan. Nilai perubahan tekanan fluida menunjukkan penurunan diantara 5,024 bar sampai dengan nilai minimum 5,005 bar.

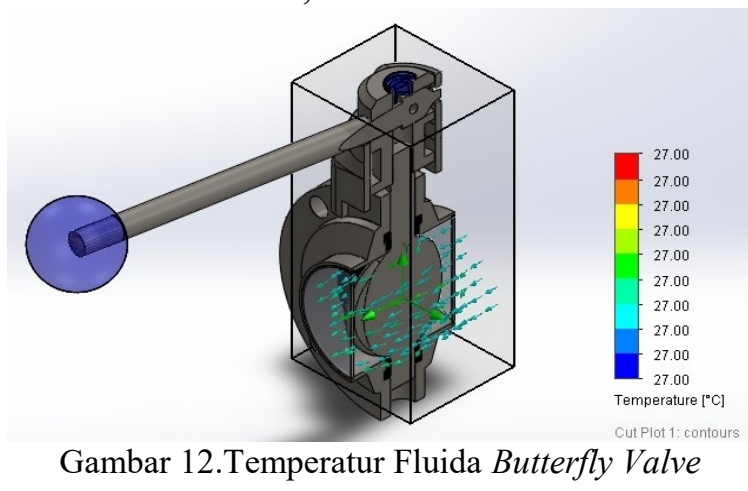


Pada gambar diatas menunjukkan pada temperatur fluida alirannya konstan dan tidak terdapat pembeban yang besar pada inlet maupun outletnya. Grafik perubahan temperatur fluida dapat dilihat pada Gambar 13.

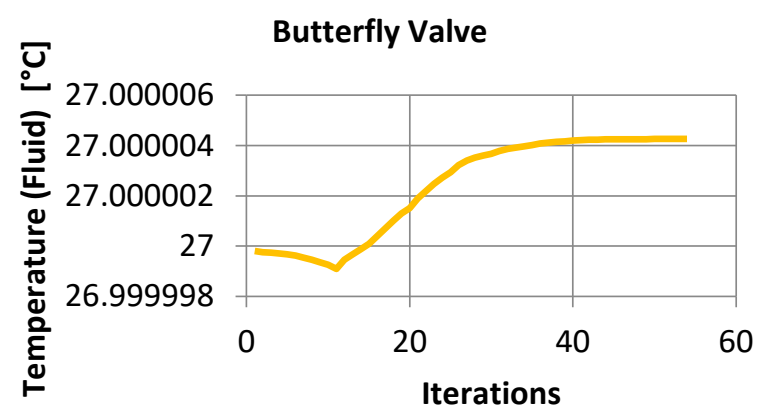

Gambar 13. Grafik Temperatur Fluida Butterfly Valve

Pada Gambar 13 diatas menunjukan pada saat kondisi full open, temperatur fluida menunjukkan adanya perubahan peningkatan. Nilai perubahan temperatur fluida menunjukkan peningkatan nilai awal $26,99^{\circ} \mathrm{C}$ naik kembali sampai dengan nilai tertinggi $27,04^{0} \mathrm{C}$.

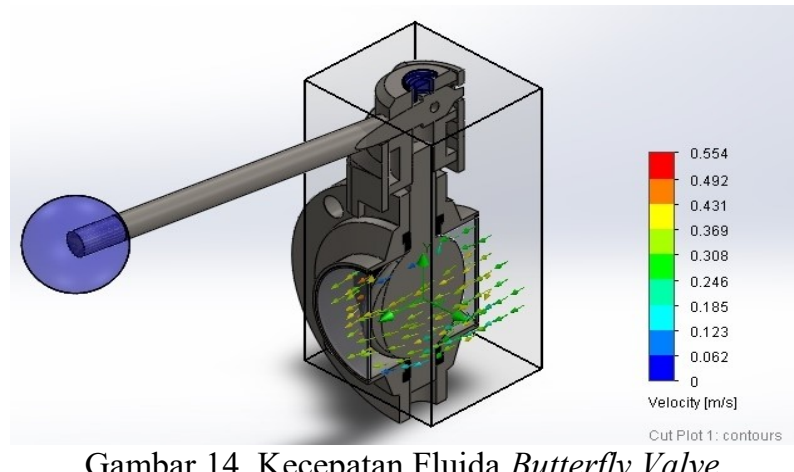

Pada gambar diatas menunjukkan pada kecepatan fluida alirannya terjadi perubahan di tengah dan terdapat pembeban yang besar pada buka katup. Grafik perubahan kecepatan fluida dapat dilihat pada Gambar15.

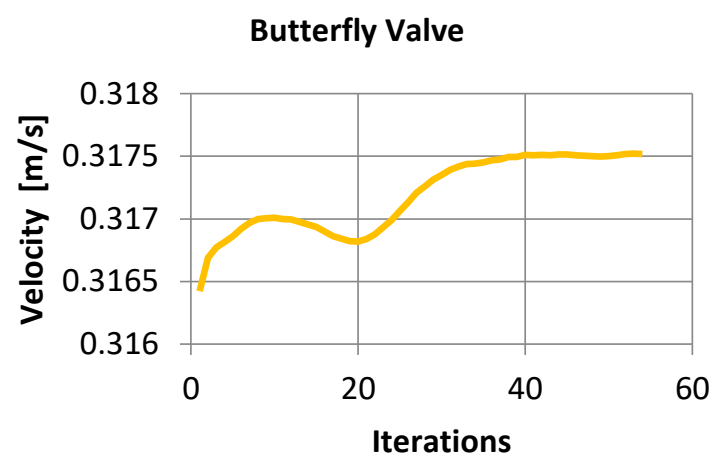

Gambar 15. Kecepatan Fluida Butterfly Valve

Pada grafik diatas menunjukan pada saat kondisi full open, kecepatan fluida menunjukkan adanya peningkatan perubahan. Nilai perubahan kecepatan fluida menunjukkan peningkatan $0,316 \mathrm{~m} / \mathrm{s}$ sampai $0,317 \mathrm{~m} / \mathrm{s}$. 
Tabel 4. Analisa Metode Flow Simulasi Computational Fluid Dynamics Pada Butterfly Valve

\begin{tabular}{|l|l|c|c|c|c|}
\hline $\begin{array}{c}\text { Butterfly } \\
\text { Valve }\end{array}$ & Unit & Value & $\begin{array}{c}\text { Averaged } \\
\text { Value }\end{array}$ & $\begin{array}{c}\text { Minimum } \\
\text { Value }\end{array}$ & $\begin{array}{c}\text { Maximum } \\
\text { Value }\end{array}$ \\
\hline Pressure & {$[\mathrm{bar}]$} & 5,005 & 5 & 5,005 & 5,024 \\
\hline Temperature & {$\left[{ }^{\circ} \mathrm{C}\right]$} & 26,99 & 27 & 26,99 & 27,04 \\
\hline Velocity & {$[\mathrm{m} / \mathrm{s}]$} & 0,316 & 0,5 & 0,316 & 0,317 \\
\hline
\end{tabular}

\subsection{Grafik Perbandingan Ball Valve dan Butterfly Valve}

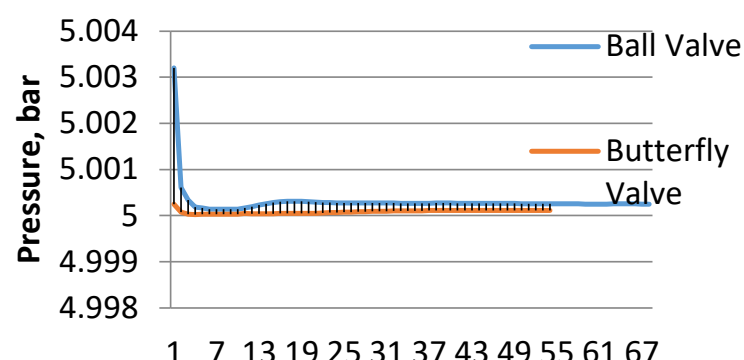

Gambar 16. Perbandingan Pressure

Pada grafik diatas tekanan fluida pada ball valve lebih sedikit tinggi dibandingkan tekanan fluida pada butterfly valve. Karena ball valve memiliki buka tutup katup lebih cepat dibanding butterfly valve.

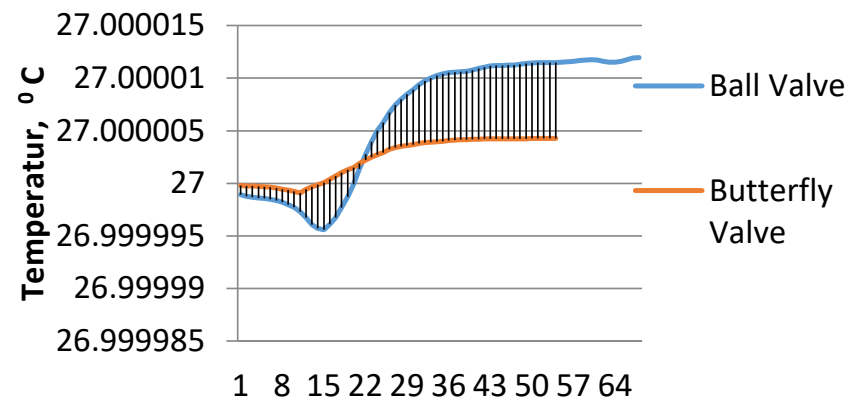

Gambar 17. Perbandingan Temperature

Pada grafik diatas temperatur fluida menunjukan peningkatan pada butterfly valve dan penurunan pada ball valve. kemudian pada tahap dipertengahan, ball valve jauh meningkat hingga $27,010^{\circ} \mathrm{C}$ dan butterfly valve hanya meningkat sampai $27,005^{\circ} \mathrm{C}$. 


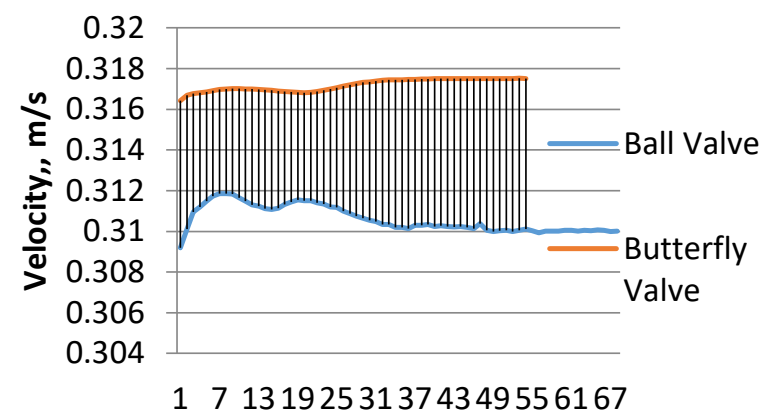

Gambar 18. Perbandingan Velocity

Pada grafik diatas menunjukan nilai kecepatan butterfly valve lebih tinggi dibandingkan ball valve, karena adanya gesekan antara seat dengan disc yang membuat alirannya lebih deras atau kencang dibanding ball valve.

\section{PENUTUP}

\section{Kesimpulan}

Analisa pada ball valve dan butterfly valve pada penelitian ini dapat disimpulkan bahwa ball valve memiliki nilai pressure minimum 5,03 bar dan nilai maksimum 5,10 bar. Kemudian nilai temperature minimum $26,95^{\circ} \mathrm{C}$ dan nilai maksimum $27,12^{0} \mathrm{C}$. Lalu nilai velocity minimum $0,301 \mathrm{~m} / \mathrm{s}$ dan maksimum $0,313 \mathrm{~m} / \mathrm{s}$. Pada butterfly valve memiliki nilai pressure minimum 5,005 bar dan maksimum 5,024 bar. Kemudian nilai temperature minimum $26,99^{\circ} \mathrm{C}$ dan maksimum $27,04^{0} \mathrm{C}$. Lalu nilai velocity minimum $0,316 \mathrm{~m} / \mathrm{s}$ dan maksimum $0,317 \mathrm{~m} / \mathrm{s}$.

Dan terlihat juga dari grafik pada perbandingan ball valve dan butterfly valve. Pressure ball valve lebih sedikit tinggi dibanding butterfly valve, kemudian pada temperature ball valve lebih meningkat dari pada butterfly valve meskipun ball valve sempat mengalami penurunan dan kembali meningkat, lalu pada velocity menunjukan butterfly valve lebih tinggi dibanding ball valve.

Setelah melakukan analisa dan perbandingan pada kedua valve tersebut, hendaknya mengetahui apa saja parameter yang digunakan dalam mencari analisa yang akan diteliti dan pemilihan material juga menjadi perhatian karena berpengaruh signifikan dalam hasil analisa dengan menggunakan metode CFD ini.

\section{Daftar Pustaka}

A. Tabrizi, M. Asadi, G. Xie, G. Lorenzini and C. Biserni, "Computational Fluid-DynamicsBased Analysis of a Ball Valve Performance in the Presence of Cavitation," Journal of Engineering Thermophysics Vol. 23 No.1, pp. 27-38, 2014.

Bi, Z., 2018. Overview of Finite Element Analysis. In: Finite Element Analysis Applications A Systematic and Practical Approach. London: Katey Birtcher, pp. 1-29. 
Dantulwari, N., Maske, R. \& Patel, J., 2017. Finite Element Analysis of Ball Valve Assembly for Earthquakes. International Conference on Ideas, Impact and Innovation in Mechanical Engineering, 5(6), pp. 1460-1467.

Hidayat, M.F. and Nofendri, Y., 2018. PEMILIHAN SUDUT SERANG TERBAIK SAYAP PESAWAT AIRFOIL NACA 0013 SAAT TAKE OFF MENGGUNAKAN ANSYS FLUENT. Jurnal Konversi Energi dan Manufaktur UNJ, 5(2), pp.58-66.

Kaidir, 2014. “Termodinamika Teknik Jilid 1”. Bung Hatta University Press.

Mandanaka, P., Tadvi, K. M. \& Raiyani, P. H., 2016. Modeling and FEA Analysis of Ball Valve. International Journal of Engineering Development and Research, 4(2), pp. 1022-1026.

Meri Rahmi ${ }^{1}$, Dellfika canra ${ }^{2}$, Suliono ${ }^{3}$. 2018. “Analisis Perbedaan Tekanan Fluida pada Ball Valve Kondisi Full Closed dan Full Open dengan Computational Fluid Dynamics". Jurnal Teknologi Terapan.

Meri Rahmi ${ }^{1}$, Dellfika canra ${ }^{2}$, Suliono ${ }^{3}$. 2018. “Analisa Kekuatan Ball Valve Akibat Tekanan Fluida Menggunakan Finite Element Analysis”. Jurnal Teknologi Terapan

Paul, P. E. S., Kumar, G. U., Durairaj, S. \& Sundarrajan, D., n.d. Design and Analysis of Industrial Ball Valve using Computational Fluid Dynamics. International Journal of Recent Trends in Mechanical Engineering.

Utami, M. B. et al., n.d. Pengukuran Compressive Strength Benda Padat. Compressive Strength 